\title{
BEACH PROFILE CHANGE MEASURED IN THE TANK FOR LARGE WAVES 1956-1957 AND 1962
}

\section{US Army Corps \\ of Engineers}

\author{
by
}

\author{
Nicholas C. Kraus \\ Coastal Engineering Research Center \\ DEPARTMENT OF THE ARMY \\ Waterways Experiment Station, Corps of Engineers \\ PO Box 631, Vicksburg, Mississippi 39180-0631 \\ and \\ Magnus Larson \\ Department of Water Resources Engineering \\ Institute of Science and Technology \\ University of Lund \\ Box 118, Lund, Sweden S-22100
}

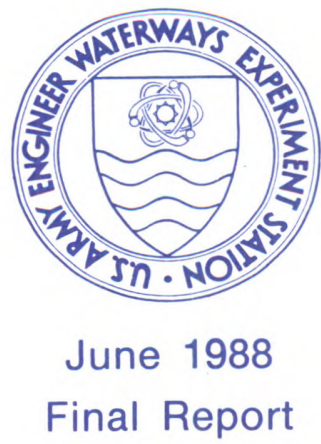

Approved For Public Release; Distribution Unlimited

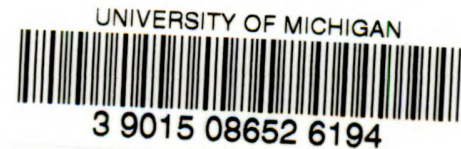

Prepared for DEPARTMENT OF THE ARMY US Army Corps of Engineers Washington, DC 20314-1000

Under Surf Zone Sediment Transport Processes Work Unit 34321 